\title{
Proteomic Identification of Allergenic Proteins of Morus alba L. Pollen
}

\author{
Demirhan ÇETEREİSİ, ${ }^{1}$ Nurgül KARLIOĞLU, ${ }^{2}$ Asl GELINCÍK, ${ }^{3}$ Sylvie MICHELLAND, ${ }^{4,5,6}$ Evren ÖNAY-UÇAR, ${ }^{1}$ \\ Belkıs ERTEK, ${ }^{3}$ Nilgün AKDENIZZ, Sacide ERDEN, ${ }^{8}$ Bahattin ÇOLAKOĞLU, ${ }^{3}$ Ünal AKKEMIKK, ${ }^{2}$ Günnur DENIZZ, ${ }^{7}$ Murat PEKMEZ, ${ }^{1}$ \\ Hèlène FLAMANT-WARET, ${ }^{4,5,6}$ Sylvia LEHMANN, ${ }^{4,5,6}$ Sandrine BOURGOIN-VOILLARD, ${ }^{4,5,6}$ Michel SĖVE, ${ }^{4,5,6}$ \\ Suna BÜYÜKÖZTÜRK, ${ }^{3}$ Nazlı ARDA ${ }^{1 *}$
}

\begin{abstract}
Background: Tree pollens are well-known aeroallergens all over the world. Little is known about the allergenicity of Morus alba (white mulberry) pollen.
\end{abstract}

Objective: We aimed to explore the potential allergens of this pollen and its clinical relevance in tree pollen allergic patients living in Istanbul, Turkey.

Methods: Twenty three seasonal allergic rhinitis patients with a confirmed tree pollen allergy and 5 healthy control subjects underwent skin prick and nasal provocation tests with M.alba pollen extract. The pollen extract was then resolved by gel electrophoresis, and immunoblotted with sera from patients/control individuals to detect the potential allergenic proteins. The prevalent IgE binding proteins from 1D-gel were analyzed by MALDI-TOF/TOF.

Results: Eleven out of 23 patients were reactive to the extract with skin prick tests. Seven of those patients also reacted positively to the nasal provocation tests. The most common IgE-binding pollen proteins were detected between $55-100 \mathrm{kDa}$, and also at molecular weights lower than $30 \mathrm{kDa}$ for some patients. Mass spectrometry analyses revealed that the principal IgE-binding protein was methionine synthase (5-methyltetrahydropteroyltriglutamate homocysteine methyltransferase), which is then proposed as a novel allergen in M.alba pollen.

Conclusion: This study provides the first detailed information for the potential allergens of Morus alba pollen of Istanbul. Methionine synthase with an apparent molecular weight of 80 to $85 \mathrm{kDa}$ has been recognized as one of the allergens in Morus alba pollen for the first time.

Key words: IgE-binding proteins, methionine synthase (MetE), Moraceae, Morus alba, pollen allergy, white mulberry

\section{From:}

${ }^{1}$ Department of Molecular Biology and Genetics, Faculty of Science, Istanbul University, Istanbul, Turkey

${ }^{2}$ Department of Forest Botany, Faculty of Forestry, Istanbul University Cerrahpasa, Istanbul, Turkey

Allergy Section, Department of Internal Medicine,

Istanbul Faculty of Medicine, Istanbul University, Istanbul, Turkey

${ }^{4}$ PROMETHEE Proteomic Platform, LBFA and BEeSy, University Grenoble Alpes, Grenoble, France

${ }^{5}$ PROMETHEE Proteomic Platform, Inserm, IAB, Grenoble, France

${ }^{6}$ PROMETHEE Proteomic Platform, Institut de Biologie et de Pathologie, CHU Grenoble Alpes, Grenoble, France

Department of Immunology, Aziz Sancar Institute of Experimental Medicine, Istanbul University, Istanbul, Turkey

${ }^{8}$ Department of Internal Medicine, Istanbul Faculty of Medicine, Istanbul University, Istanbul, Turkey

\footnotetext{
* Corresponding author:

Nazlı Arda

Department of Molecular Biology and Genetics, Faculty of Science, Istanbul University, Vezneciler, 34134 Istanbul, Turkey Email: narda@istanbul.edu.tr
}

\section{Introduction}

Tree pollens are well-known aeroallergens all over the world. When they are released into the atmosphere in sufficient amounts, they can cause various allergic diseases such as asthma, rhinitis and conjunctivitis in sensitive individuals, especially in their pollen spreading periods., ${ }^{1,2}$ Pollen proteins and glycoproteins with molecular weights of 5-150 kDa are primarily responsible for allergenicity. ${ }^{3}$ Proteomic studies represent a quick and efficient way of identifying protein(s) of interest and characterizing complex allergen sources. The combination of 
immunoblotting with 1-D or 2-D gel electrophoresis provides an opportunity to detect Ig-E binding proteins in more detail after protein separation depending on their isoelectric points and/or molecular weights. After the detection of IgE binding proteins, they can be identified efficiently by mass spectrometry (MS). ${ }^{4}$ Such an effort may help to extend the efficiency of both diagnostic and therapeutic tools for allergic diseases. ${ }^{5}$ The protein family distribution of pollen allergens is regarded as up to 29 families $^{6}$ while tree pollen allergens are mostly found in pathogenesis-related group 10 (PR-10 or Bet $\mathrm{v}$ I-related) proteins, profilins, calcium binding proteins (polcalcins), expansins and pectate lyases. ${ }^{7}$

Mulberry (Morus) is a genus of the Moraceae family, which comprises native or cultivated trees in mild regions of the world. The fruits are consumed by humans as food and as traditional medicine, and the leaves are used as animal feed for both silkworms in silk production and for farm animals. ${ }^{8}$ The Morus genus contains widespread species such as $M$. nigra (black mulberry), M. rubra (red mulberry), M. microphylla (Texas mulberry), M. papyrifera (paper mulberry) and $M$. alba (white mulberry). However, there are a limited number of studies on the allergenic proteins of these species. A non-specific lipid transfer protein (ns-LTP), Mor $\mathrm{n} 3$ from the black mulberry with a molecular mass of $9246 \mathrm{Da}$, the first isolated and completely characterized fruit allergen was shown to cross-react with other plant-derived LTPs. ${ }^{9}$ More recently a $10-\mathrm{kDa}$ protein has been proposed by Micheal et al. as an unidentified pollen allergen from the paper mulberry. ${ }^{10}$ The authors suggested that paper mulberry pollen allergens show no homology with nsLTPs or birch pollen allergens.

Some clinical studies indicate that M.alba pollen induces allergic diseases, such as asthma, allergic rhinitis, allergic conjunctivitis and urticaria, especially in pollen-spreading periods (April-May). ${ }^{11-13}$ Although white mulberry pollen is regarded as an important aeroallergen, there are a limited number of reports on its allergenicity and allergenic proteins. Navarro and coworkers demonstrated that IgE antibodies were produced against 10 - and $18-\mathrm{kDa}$ allergens from white mulberry fruit in a 46 -year-old female patient. ${ }^{13}$ The latter allergen $(18 \mathrm{kDa})$ is also present in white mulberry pollen and leaves, and has been found to cross-react with birch pollen.

The present study aimed to investigate the allergenicity of white mulberry pollen extract and to identify its allergenic proteins using the immunoproteomic approach called Serological Proteomic Analysis (SERPA). As this study was the first clinical report on Turkish population, our results have been expected to contribute both to clinical data and to pollen proteomics.

\section{Methods \\ Pollen collection}

Pollen samples from Morus alba L. were collected from the garden of Faculty of Forestry, Istanbul University (Bahçeköy -Istanbul/Turkey) during the pollen-spreading period (April/ 2012). The plants were identified by means of rigorous botanical criteria, and pollen was collected from the mature flowering plants by using, at a close distance, a filter-equipped vacuum device to avoid contamination. Pollen purity (>99\%) was assessed by microscopic analysis performed by a well-trained specialist. Pollen grains were separated with different pore size
(250, 180 and $90 \mu \mathrm{m})$ sieves, dried at room temperature, and kept at $-80^{\circ} \mathrm{C}$ until protein extraction.

\section{Preparation of pollen extract}

Pollen extraction was performed with some modifications according to Iacovacci et al. ${ }^{14}$ Ten grams of dried pollen was suspended in $125 \mathrm{mM} \mathrm{NH}_{4} \mathrm{HCO}_{3}$ at a ratio of 1:12 (w/v) for 12 hours at $4^{\circ} \mathrm{C}$ with constant stirring. Insoluble materials were removed by centrifugation at $13000 \mathrm{xg}$ for 1 hour at $4^{\circ} \mathrm{C}$. Afterwards the extract was filtered through a Whatman No. 1 filter paper with $0.45 \mu \mathrm{m}$ pore size and $125 \mathrm{~mm}$ Whatman filter paper with a Millipore vacuum filtration system. The filtrate was dialyzed for 24 hours at $4^{\circ} \mathrm{C}$ with distilled water using $43 \mathrm{~mm}$ dialysis tubing. The final dialysate was lyophilized and stored at $-80^{\circ} \mathrm{C}$.

The lyophilized pollen extract was solubilized in distilled water and the protein concentration was determined by using a Bicinchoninic Acid (BCA) Protein Assay Kit. The final absorbance of the assay mixture was measured by VarioScan Flash Image System (Bio-Rad) at a $562 \mathrm{~nm}$ wavelength.

\section{Clinical Studies}

Patient Selection: After receiving ethical approval from the Ethics Committee of Istanbul Faculty of Medicine, Ethical Committee and written informed consents from the subjects, 23 seasonal allergic rhinitis patients (16 female, 7 male; 21-56 year old) who displayed positive prick test results for common tree pollens and 5 healthy control subjects were included into the study. A pollen allergy was established by means of positive skin prick test (SPT) and nasal provocation test (NPT) results.

Skin Prick Test (SPT): A skin prick test was performed with the commercial allergen extracts from different tree pollens (Betula verrucosa, Platanus acerifolia, Quercus ilex, Cupressus arizonica, Cupressus sempervirens, Corylus avellana, Alnus glutinosa, Fagus sylvatica, Quercus robur), as well as with the prepared M.alba pollen extract. The prepared M.alba pollen extract was used for skin prick-testing in four different concentrations starting with a $1 / 1000$ diluted suspension to $1 / 1$ undiluted ( $5 \mathrm{mg} / \mathrm{mL}$ lyophilized powder) raw extract. The test was repeated with a tenfold increase in the extract concentration if the previous test was found negative. A positive response was defined as a wheal measuring at least $3 \mathrm{~mm}$ in diameter when compared with serum physiologic that was used as a negative control.

Nasal Provocation Test (NPT):Each nasal cavity was evaluated separately. Airflow was measured under $150 \mathrm{~Pa}$ pressure and resistance was calculated using an anterior rhinomanometer (Jaeger brand Masterscope Rhino Carefusion, Germany). Patients were challenged first with 2 puffs $(100 \mu \mathrm{L})$ of saline in each nostril to exclude nasal hyperreactivity. If no reaction to the physiological saline solution occurred, NPT was initiated with increasing concentrations of M.alba pollen extract in 15 -minute intervals. Two puffs $(100 \mu \mathrm{L})$ of the solution at room temperature were applied to each nostril. If a positive reaction did not occur with the previous concentration, the concentration of pollen extract was incrementally increased until the final concentration of a 1/1 undiluted form. Symptom scores and nasal resistance with anterior rhinometry were recorded before and after each provocation. Positivity criteria 
in the nasal provocation test consisted of both symptom score positivity according to the Lebel symptom score scale and changes in the measurement of rhinometry, which included a fall in peak inspiratory flow (PIF) of $\geq 40 \%$ post-NPT and/or increase in airflow resistance by $100 \% .^{15-17}$

\section{Electrophoresis}

SDS- PAGE for Western blotting was carried out as described earlier with a slight modification in sample buffer. ${ }^{18}$ Lyophilized pollen extract in distilled water was mixed with sample buffer containing $200 \mathrm{mM}$ Tris- $\mathrm{HCl}, 8 \%$ SDS, $40 \%$ glycerol and $0.04 \%$ bromophenol blue in a proper ratio, heated in a hot plate at $95^{\circ} \mathrm{C}$ for 5 minutes and 20 microgram of each sample were loaded onto the electrophoresis system (Mini -PROTEAN 3 Cell, Bio-Rad).

Protein samples were migrated on a discontinuous gel consisting of a stacking part (5\% acrylamide) and a resolving part (10\% acrylamide) under $200 \mathrm{~V}$ until the dye front reached the bottom of the gel. Proteins were visualized with Imperial Protein Stain (Thermo Scientific) based on Coomassie R-250 dye. The SDS-PAGE gel was scanned by a Chemidoc TM XRS+System (Bio-Rad).

\section{Western blotting}

Separated proteins on 1D-gel were transferred onto a PVDF membrane by a semidry blotting system (Bio-Rad) at $0.5 \mathrm{~mA} /$ gel and $25 \mathrm{~V}$ for 90 minutes. The membrane was blocked with $5 \%$ skimmed milk in phosphate buffered saline (PBS) containing $0.5 \%$ Tween 20 for 1 hour. After washing with PBS-0.5\% Tween 20, the membrane was incubated overnight with a 1:4 dilution of sera from patients or healthy control subjects at $4{ }^{\circ} \mathrm{C}$. IgE-binding proteins were detected using a 1:1000 dilution of HRP (horse radish peroxidase)-conjugated mouse anti-human $\operatorname{IgE}(\mathrm{Fc})$ antibody (Southern Biotech). Revelation was carried out using ECL Western Blotting Detection Reagents (GE-Healthcare), and the membrane was scanned by the Chemidoc TM XRS+System (Bio-Rad).

\section{Proteomic Analysis}

In Gel Digestion: Common IgE-binding protein bands from $1 \mathrm{D}$-gel were excised into small pieces and destained in $100 \mathrm{mM}$ ammonium bicarbonate and in $100 \%$ acetonitrile (ACN), alternatively, and then dried at $37^{\circ} \mathrm{C}$. In-gel digestion was performed as following: the dried gel pieces were reduced with $65 \mathrm{mM}$ DTT for 1 hour at $37^{\circ} \mathrm{C}$ and alkylated with $135 \mathrm{mM}$ iodoacetamide (IAA) for 30 minutes at room temperature in the dark. After removing the solution, the gel pieces were washed with $100 \mathrm{mM}$ ammonium bicarbonate; and an equal volume of $100 \%$ ACN was added and incubated for 10 minutes, and then dried at $37^{\circ} \mathrm{C}$. For gel digestion, MS grade trypsin (Trypsin Gold, Promega) was added to the gel pieces at $125 \mathrm{ng}$ in $0.01 \%$ surfactant (ProteaseMAX ${ }^{\mathrm{T}}$ Surfactant, Trypsin Enhancer, Promega) and incubated for 2 hours at $37^{\circ} \mathrm{C}$. The digestion was stopped by adding $0.4 \mu \mathrm{L}$ of $10 \%$ trifluoroacetic acid (TFA). The resulting peptides were concentrated by vacuum centrifuge and maintained at $-20^{\circ} \mathrm{C}$ until further analysis.
Mass spectrometric analysis: In order to remove salt and contaminants from the peptide mixture, it was purified and condensed with Zip Tip C18 tips (Millipore) and mixed with a-cyano-4 hydroxy-cinnamic acid (Sigma-Aldrich) and spotted onto target MALDI plates. The peptides were identified by the 4800 MALDI TOF/TOF mass spectrometer (ABSciex, Les Ulis, France). Data acquisition was carried out using 4000 Series Explorer software, V3.5.3 (ABSCiex) in positive reflector ion mode for both MS and MS/MS analyses. The mass spectrometer was calibrated before each analysis with Peptide Calibration Standard II (Bruker Daltonics, Bremen, Germany). MS analyses were performed within a range of $m / z 700-m / z 4000$. MS/ MS experiments were performed on the 30 most abundant ions with a threshold of $\mathrm{S} / \mathrm{N}$ higher than 30 by using CID (Collision Induced Dissociation) activation mode.

Protein Identification: Post-analysis data processing was performed using Protein Pilot 4.5 software with Mascot search engine and the protein database of National Center for Biotechnology Information (NCBI - February 2015). The sequence query searching was set up using the following parameters: carbamidomethyl (C) as fixed modification, deamidated (NQ), oxidation (HW) and oxidation (M) as variable modifications with one missed cleavage and a $\mathrm{m} / z$ tolerance of $50 \mathrm{ppm}$ for the precursor ion and a $m / z$ tolerance of $0.1 \mathrm{Da}$ for the product ions. Protein identification was based on taxonomic similarities with M. notabilis since corresponding proteins in $M$. alba have not yet been sequenced. Only protein Mascot scores greater than 70 are significant $(\mathrm{p}<0.05)$ for protein identification.

\section{IgE Measurement}

Allergen specific IgE was measured with an ELISA kit (Allercoat $^{\mathrm{TM}} 6$ Microplate ELISA, Euroimmun, Germany). Sera samples were applied to the microplate wells, which were assembled with the rings coated with commercial $M$. alba pollen extract and incubated for 60 minutes at $37^{\circ} \mathrm{C}$. After washing the microplate wells with wash buffer, a component of the kit, alkaline phosphatase labelled anti-human IgE antibody was added and incubated for 60 minutes at $37^{\circ} \mathrm{C}$. Substrate solution was added into each well and incubated for 30 minutes at $37^{\circ} \mathrm{C}$. After washing, bound conjugate was detected with p-nitrophenyl phosphate (PNPP) by incubating for 30 minutes at $37^{\circ} \mathrm{C}$. The reaction was stopped with $1 \mathrm{M} \mathrm{NaOH}$ and read at $405 \mathrm{~nm}$ on an ELISA reader. ELISA for prepared M.alba pollen extract could not be performed due to a lack of availability of the relevant allergen ring coated with this extract.

\section{Results \\ Skin prick tests}

Eleven of 23 patients who were sensitized to one or more standardized tree pollens (ALK-Abello, Spain) reacted to Morus alba L. pollen extract in different concentrations (1 patient with $1 / 100$ dilution, 3 patients with $1 / 10$ dilution, and 7 patients with the undiluted extract). None of the healthy control subjects reacted to the SPT. The skin prick test results of 11 patients (A-K) with $M$. alba pollen and other standard tree pollens are presented in Table 1. The most prevalent tree pollen reactivities were against Cupressus arizonica (9 patients) and Platanus acerifolia (7 patients). 
Table 1. Skin prick test results for Morus alba L. pollen extract and some other commercial tree pollen extracts.

\begin{tabular}{|c|c|c|c|c|c|c|c|c|c|c|c|}
\hline \multirow{2}{*}{ Patient } & \multirow{2}{*}{ Mora } & \multicolumn{10}{|c|}{ Commercial pollen extracts } \\
\hline & & Betv & Plaa & Quei & Cupa & Cups & Cora & Alng & Fags & Pins & Quer \\
\hline A & $4 \mathrm{~mm}$ & $4 \mathrm{~mm}$ & $4 \mathrm{~mm}$ & - & $4 \mathrm{~mm}$ & $5 \mathrm{~mm}$ & - & $5 \mathrm{~mm}$ & $5 \mathrm{~mm}$ & - & $5 \mathrm{~mm}$ \\
\hline $\mathrm{B}$ & $5 \mathrm{~mm}$ & - & - & - & - & - & - & - & - & - & - \\
\hline $\mathrm{C}$ & $4 \mathrm{~mm}$ & - & - & - & - & - & $4 \mathrm{~mm}$ & $4 \mathrm{~mm}$ & - & - & - \\
\hline $\mathrm{D}$ & $5 \mathrm{~mm}$ & $4 \mathrm{~mm}$ & $5 \mathrm{~mm}$ & - & $5 \mathrm{~mm}$ & - & - & - & - & - & - \\
\hline $\mathrm{E}$ & $4 \mathrm{~mm}$ & - & - & $4 \mathrm{~mm}$ & $4 \mathrm{~mm}$ & $4 \mathrm{~mm}$ & $4 \mathrm{~mm}$ & $4 \mathrm{~mm}$ & $4 \mathrm{~mm}$ & - & - \\
\hline $\mathrm{F}$ & $4 \mathrm{~mm}$ & $4 \mathrm{~mm}$ & $5 \mathrm{~mm}$ & $4 \mathrm{~mm}$ & $4 \mathrm{~mm}$ & $4 \mathrm{~mm}$ & - & - & - & - & + \\
\hline G & $5 \mathrm{~mm}$ & - & $4 \mathrm{~mm}$ & - & $5 \mathrm{~mm}$ & - & - & - & - & - & - \\
\hline $\mathrm{H}$ & $5 \mathrm{~mm}$ & - & - & - & $5 \mathrm{~mm}$ & - & - & - & - & - & - \\
\hline I & $5 \mathrm{~mm}$ & - & $4 \mathrm{~mm}$ & - & $6 \mathrm{~mm}$ & - & $4 \mathrm{~mm}$ & - & - & - & - \\
\hline $\mathrm{J}$ & $4 \mathrm{~mm}$ & - & $4 \mathrm{~mm}$ & - & $4 \mathrm{~mm}$ & $5 \mathrm{~mm}$ & $5 \mathrm{~mm}$ & $4 \mathrm{~mm}$ & - & - & - \\
\hline $\mathrm{K}$ & $4 \mathrm{~mm}$ & $4 \mathrm{~mm}$ & $4 \mathrm{~mm}$ & $4 \mathrm{~mm}$ & $4 \mathrm{~mm}$ & $4 \mathrm{~mm}$ & - & $4 \mathrm{~mm}$ & $4 \mathrm{~mm}$ & $4 \mathrm{~mm}$ & $5 \mathrm{~mm}$ \\
\hline
\end{tabular}

Mora, Morus alba; Betv, Betula verrucosa; Plaa, Platanus acerifolia; Quei, Quercus ilex; Cupa, Cupressus arizonica; Cups, Cupressus sempervirens; Cora, Corylus avellana; Alng, Alnus glutinosa; Fags, Fagus sylvatica; Pins, Pinus sylvestris; Quer, Quercus robur; (+) indicates positive response, (-) indicates no response to the pollen sample in patient.

\section{Nasal provocation tests}

Nasal provocation with $M$. alba pollen extract was conducted with 23 patients. Seven out of 11 SPT $(+)$ patients $(A-G)$ were also NPT $(+)$ whereas $2(\mathrm{H}$ and $\mathrm{I})$ were negative and $2(\mathrm{~J}$ and $\mathrm{K}$ ) were hyperreactive. Five of the remaining 12 SPT (-) patients were hyperreactive while 4 patients reacted to different concentrations of pollen extract in the NPT. Three of the SPT (-) patients were also NPT (-). None of the healthy control subjects reacted to the NPT.

\section{Detection of IgE-binding proteins by 1D-SDS PAGE and im- munoblotting}

The SDS-PAGE of the $M$. alba pollen extract indicated at least 18 proteins (Figure 1a). These proteins were then transferred to a PVDF membrane without staining for the detection of IgE-binding capacity using Western blotting. Each blot was individually incubated with the sera of the 23 seasonal allergic rhinitis patients and 5 healthy control subjects. Specific IgEs against M.alba polypeptides were detected in 11 out of 23 patients' sera (Figure 1b). The results have been evaluated with both SPT and NPT results. The $1 \mathrm{D}$-immunoblotting profile resulting from interaction between specific IgEs of patient $\mathrm{F}$ and M. alba pollen proteins is presented in Figure 1c. IgE antibodies of the remaining 12 patients and of the control individuals did not react with the pollen proteins.

Immunoblots showed that $M$. alba pollen contained common IgE-binding polypeptides between $55-100 \mathrm{kDa}$. One protein with a molecular weight of $80 \mathrm{kDa}$ produced a significant reaction in 5 patients (A, C, E, F and $\mathrm{K}$ ). IgE-binding protein(s) with a molecular weight of $<30 \mathrm{kDa}$ were also detected. These small proteins were predominant in one of the hyperreactive patients $(\mathrm{J})$ whereas the $80 \mathrm{kDa}$ protein was predominant in hyperreactive patient $(\mathrm{K})$. Polypeptide bands corresponding to the identified allergens were excised from the polyacrylamide gel and analyzed by MS/MS analysis.

\section{Identification of potential allergenic proteins}

Common IgE-binding protein bands (Band 1-5 from 1D-gel in Figure 1a) were excised, digested by trypsin and analyzed using MALDI TOF/TOF mass spectrometer for protein identification. To check the accuracy of this experiment, a $50 \mathrm{kDa}$ marker protein was also analyzed and the protein was identified with a high score (431). Only the proteins identified with significant Mascot scores were summarized in Table 2 (for detailed information, see Tables S1-5). It should be mentioned that the database research was conducted by similitudes to M. notabilis, a recently sequenced Morus species as the complete sequences of proteins in $M$. alba are still not well understood. ${ }^{19,20}$ Band 1 matched with two isoforms of methionine synthase(5-methyltetrahydropteroyltriglutamate-homocysteine methyltransferase) with a Mascot protein scores of 353 and 215. Two isoforms of L-ascorbate oxidase-like protein were also identified from band 1, but with much lower scores (173 and 87 ). One isoform of L-ascorbate oxidase-like protein was also identified from band 2, which was very close to band 1 . The calculated masses from the primary sequences of both L-ascorbate oxidase-like protein isoforms is around $60-62 \mathrm{kDa}$, a value lower than the observed masses for band 1 and 2 of 82 and $79 \mathrm{kDa}$, respectively. This difference could be explained by a glycosylation, well described for several ascorbate oxidase enzymes in pollens. ${ }^{21}$

A phosphoglucomutase and the subtilisin-like protease SDD1 were both identified in band 3 (observed mass of 68 $\mathrm{kDa}$ ). Band 4 and band 5 also gave positive results with the identified proteins hypothetical protein L484_006703, a protein from the glycosyl hydrolase family 9 and hypothetical protein L484_025194 with a conserved domain found in a variety of structurally related metalloproteins like glyoxalase I or dioxygenases. However, these proteins are less significant with mascot scores of 71 and 73 , respectively, close to the threshold score of 60 used for the validation of Mascot identifications. 
(a)

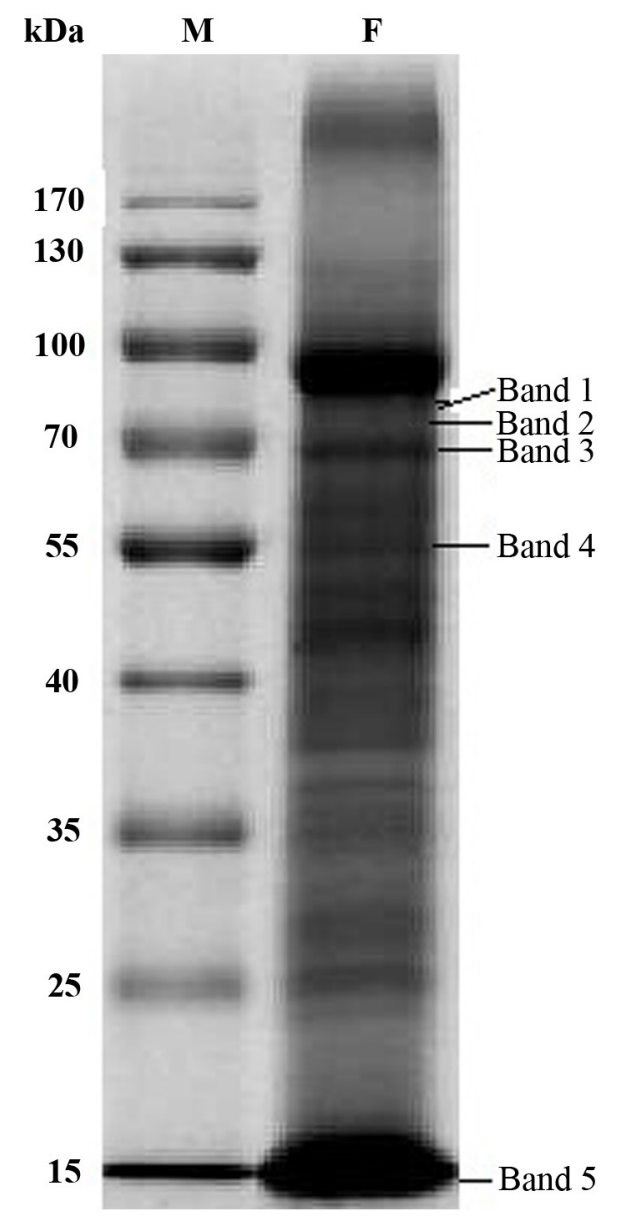

(b)

Skin prick test (SPT)/Nasal provocation test (NPT): +/+

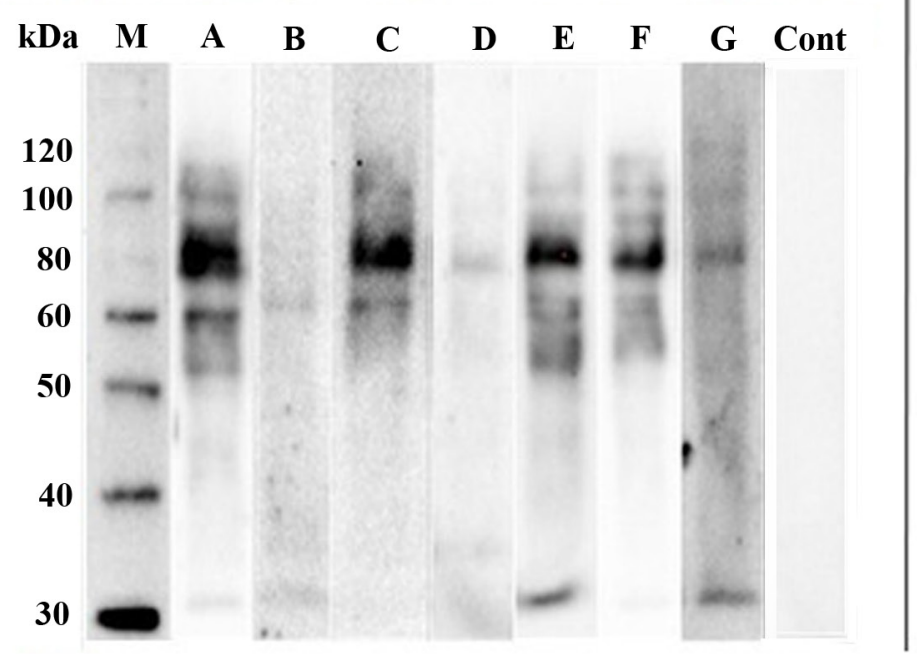

(c)

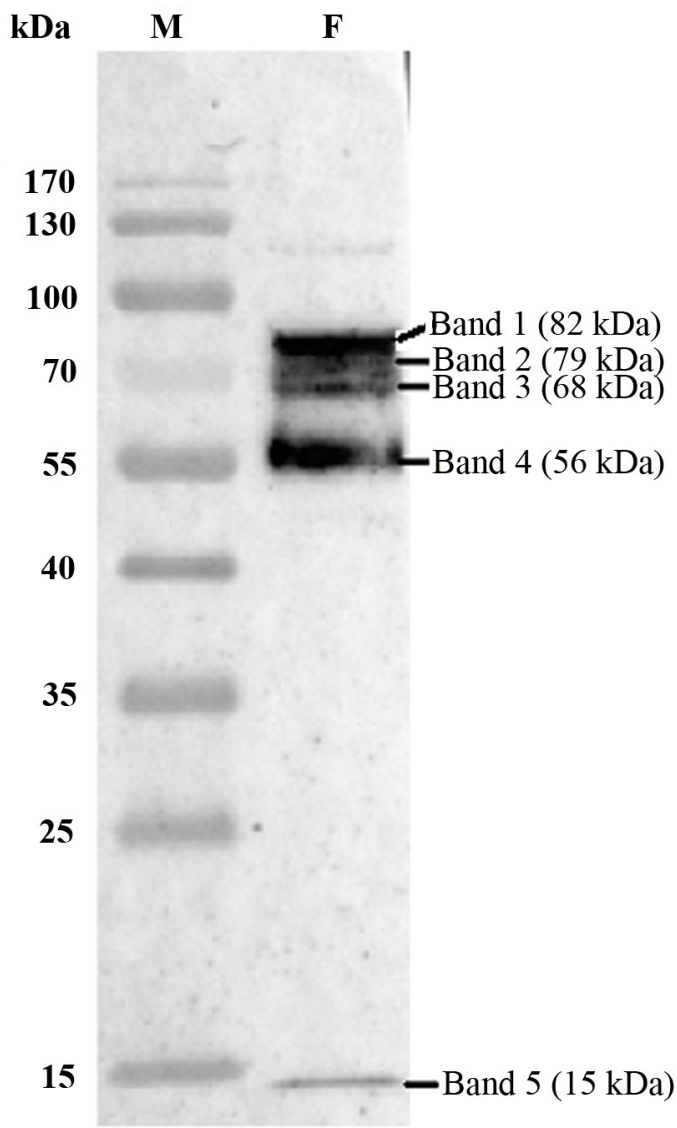

SPT/NPT: +/-

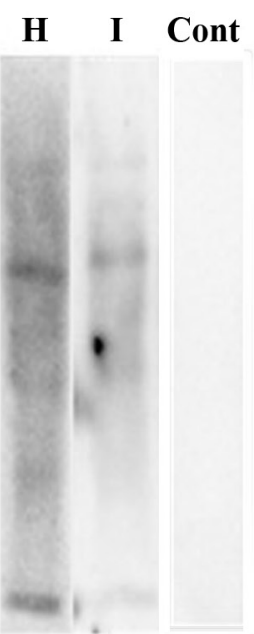

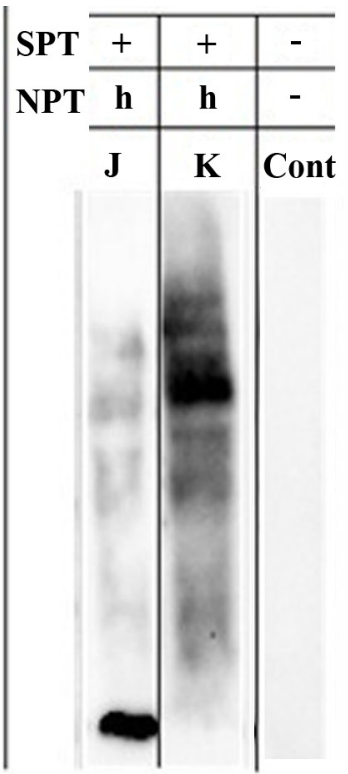

Figure 1. (a) 1-D Coomassie blue stained protein profile of Morus alba L. pollen; (b) IgE immunoblotting analysis of the sera of 11 patients (1-11) with Morus alba L. pollen extract. Patients were presented in three classes of clinical response; (c) 1D-immunoblotting result from patient F serum. M, molecular weight markers (PageRuler Prestained Protein Ladder (Thermo Scientific) in (a) and MagicMark XP Western Protein Standard (Life Technologies) in (b) and (c); Cont., serum sample from healthy control subjects; $h$, hypersensitive; Mora: Morus alba. 
Table 2. The potential allergenic proteins of Morus alba L. pollen.

\begin{tabular}{|c|c|c|c|c|c|c|c|}
\hline & Protein names & $\begin{array}{l}\text { Accession } \\
\text { number }\end{array}$ & $\begin{array}{l}\text { Calculated } \\
\text { Molecular } \\
\text { Mass (Da) }\end{array}$ & $\begin{array}{l}\text { Observed } \\
\text { Molecular } \\
\text { Mass (Da) }\end{array}$ & $\begin{array}{l}\text { Mascot } \\
\text { Score }\end{array}$ & $\begin{array}{c}\text { Matches } \\
\text { (\# Peptides) }\end{array}$ & $\begin{array}{c}\text { Protein } \\
\text { sequence } \\
\text { coverage } \\
(\%)\end{array}$ \\
\hline \multirow[t]{4}{*}{ Band 1} & $\begin{array}{l}\text { 5-methyltetrahydropteroyltriglutamate-homocysteine } \\
\text { methyltransferase }\end{array}$ & XP_010097930 & 84904 & 82000 & 353 & 19 & 18 \\
\hline & $\begin{array}{l}\text { 5-methyltetrahydropteroyltriglutamate-homocysteine } \\
\text { methyltransferase }\end{array}$ & XP_010103482 & 83389 & 82000 & 215 & 17 & 17 \\
\hline & L-ascorbate oxidase-like protein & XP_010093150 & 60499 & 82000 & 173 & 26 & 23 \\
\hline & L-ascorbate oxidase-like protein & XP_010093149 & 62333 & 82000 & 87 & 18 & 21 \\
\hline Band 2 & L-ascorbate oxidase-like protein & XP_010093150 & 60499 & 79000 & 103 & 22 & 23 \\
\hline \multirow[t]{2}{*}{ Band 3} & Subtilisin-like protease SDD1 & XP_010108074 & 85546 & 68000 & 115 & 19 & 20 \\
\hline & Phosphoglucomutase & XP_010101975 & 63757 & 68000 & 107 & 22 & 27 \\
\hline Band 4 & hypothetical protein L484_006703 & XP_010112623 & 53747 & 56000 & 71 & 6 & 9 \\
\hline Band 5 & hypothetical protein L484_025194 & XP_010106438 & 16003 & 15000 & 73 & 9 & 48 \\
\hline
\end{tabular}

Table S1. Protein identification of band $1(82 \mathrm{kDa}), 5$-methyltetrahydropteroyltriglutamate--homocysteine methyltransferase, protein score 353 (A), 5-methyltetrahydropteroyltriglutamate--homocysteine methyltransferase, protein score 215 (B), L-ascorbate oxidase-like protein, protein score 173 (C), L-ascorbate oxidase-like protein, protein score 87 (D).

A.

\begin{tabular}{|c|c|c|c|c|c|c|}
\hline Protein name & $\begin{array}{c}\text { Accession } \\
\text { number }\end{array}$ & Mass & Score & pI & Matches & $\begin{array}{c}\text { Protein } \\
\text { sequence } \\
\text { coverage }(\%)\end{array}$ \\
\hline 5-methyltetrahydropteroyltriglutamate-homocysteine methyltransferase & XP_010097930.1 & 84904 & 353 & 6.42 & 19 & 18 \\
\hline
\end{tabular}

Protein sequence coverage (Matched peptides shown in bold red):

$\begin{array}{rlllll}\mathbf{1} & \text { MASHIVGYPR } & \text { VGPKRELKFA } & \text { LESFWDGKSS } & \text { AEDLQKVAAD } & \text { LRASIWKQMS } \\ \mathbf{5 1} & \text { EAGIKYIPSN } & \text { TFSYYDQVLD } & \text { TTAMLGAVPP } & \text { RYGWNGGEIG } & \text { FDVYFSMARG } \\ \mathbf{1 0 1} & \text { NASVPAMEMT } & \text { KWFDTNYHYI } & \text { VPELSPEIKF } & \text { SYASHKAVEE } & \text { YKEAKALGVE } \\ \mathbf{1 5 1} & \text { TVPVLVGPVS } & \text { YLLLSKPAKG } & \text { VEKSFSLLSL } & \text { IGSILPVYKE } & \text { VLAELKAAGA } \\ \mathbf{2 0 1} & \text { TWVQFDEPTL } & \text { VKDLDAHQLQ } & \text { AFTHAYSELE } & \text { SSLSGLNVVI } & \text { ETYFADVTAE } \\ \mathbf{2 5 1} & \text { AFKTLTGLKG } & \text { VTGYGFDLVR } & \text { GTKTLDLIKG } & \text { GFPSGKYLFA } & \text { GVVDGRNIWA } \\ \mathbf{3 0 1} & \text { NDLASSLSTL } & \text { EALEGIVGKD } & \text { KLVVSTSCSL } & \text { LHTAVDLVNE } & \text { TKLDKEIKSW } \\ \mathbf{3 5 1} & \text { LAFAAQKVVE } & \text { VNALAKALAG } & \text { QKDEAFFTAN } & \text { AGAQASRRSS } & \text { PRVTNEAVQK } \\ \mathbf{4 0 1} & \text { AAAALKGSDH } & \text { RRATNVSSR } & \text { DAQQKKLNLP } & \text { ALPTTTIGSF } & \text { PQTLELRRVR } \\ \mathbf{4 5 1} & \text { REYKAKKISE } & \text { EEYVNAIKEE } & \text { IKKVVKLQEE } & \text { LDIDVLVHGE } & \text { PERNDMVEYF } \\ \mathbf{5 0 1} & \text { GEQLSGFAFT } & \text { VNGWVQSYGS } & \text { RCVKPPIIYG } & \text { DVSRPKPMTV } & \text { FWSSFAQSTT } \\ \mathbf{5 5 1} & \text { KRPMKGMLTG } & \text { PVTILNWSFV } & \text { RNDQPRFETC } & \text { YQIALAIKDE } & \text { VEDLEKAGIT } \\ \mathbf{6 0 1} & \text { VIQIDEAALR } & \text { EGLPLRKSEE } & \text { AFYLNWAVHS } & \text { FRITNCGVQD } & \text { TTQIHTHMCY } \\ \mathbf{6 5 1} & \text { SNFNDIIHSI } & \text { IDMDADVITI } & \text { ENSRSDEKLL } & \text { SVFREGVKYG } & \text { AGIGPGVYDI } \\ \mathbf{7 0 1} & \text { HSPRIPSREE } & \text { IADRINKMLA } & \text { VLESNILWVN } & \text { PDCGLKTRKY } & \text { SEVKPALSNM }\end{array}$
751 VAAAKLLRSQ LASAK

B.

\begin{tabular}{|l|c|c|c|c|c|}
\hline Protein name & $\begin{array}{c}\text { Accession } \\
\text { number }\end{array}$ & Mass & Score & pI & $\begin{array}{c}\text { Matches } \\
\text { Protein } \\
\text { sequence } \\
\text { coverage (\%) }\end{array}$ \\
\hline 5-methyltetrahydropteroyltriglutamate-homocysteine methyltransferase & XP_010103482.1 & 83389 & 215 & 5.96 & 17 \\
\hline
\end{tabular}


Protein sequence coverage (Matched peptides shown in bold red):

\begin{abstract}
1 MASHIVGYPR
51 MTKWFDTNYH

101 VSYLLLSKPA

151 TLVLDLDSHK

201 KGVTAYGFDF

251 KGVTAYGFDF

301 TLKSLEGIVG

351 VEFNALANAL

401 DHRRATNVST

451 DVYVKAIKVE

501 VNGWVQSYGS

551 PVTILNWSFV

601 EGLPLRKSEQ

651 IDMDADVITI

701 IADRINKMLA
\end{abstract}

MGPERELKFA
FIIPELGPNV
KSIGNTFSFL
YEAFKNAYAA
VRGTNTIDLV
VRGTTTIDLV
KDKLVVSTSC
AGQKDEAYFS
RLDAQQKKLN
ISKVVKLQEE
RCVKPPIIYG
RNDQPRFETC
AFYLDWAVHS
ENSRSNEKLL
VLETNILWVN

MGPERELKFA

LESFWDGKSS

TFSYASHKAV

SLLDKILPIY

LESTLSGLNV

KESTLSGLNV

KGGFPHGKYL

SLLHTAVDLV

NNAAAQASRR

LPILPTTTIG

LDIDVLVHGE

DVSRPNLMTV

DQIALAIKDE

FRITNYGVQD

SVFREGVKYD

PNCGLKTRKY

$\begin{array}{ll}\text { ADDFKKFSMA } & \text { RGNSSVPAME } \\ \text { DEYKEAKSIG } & \text { VDTVPVLIGP } \\ \text { KEVISELKVA } & \text { GVTWIHFDEP } \\ \text { LVETYFTDVT } & \text { AEAYKTISEL } \\ \text { LVETYFTDVT } & \text { AEAYKTISEL } \\ \text { FAGVVDGRNI } & \text { WTNDLDASLS } \\ \text { NETKLDKEIK } & \text { SWLAFAAQKI } \\ \text { SSPRVTNEAV } & \text { QKAAAALRGS } \\ \text { CKVGVNFSLR } & \text { IGTVLLRISE } \\ \text { PERNDMVEYF } & \text { GEQLSGFAFT } \\ \text { FWSSAAQSFT } & \text { ARPMKGMLTG } \\ \text { VEDLEKAGIN } & \text { VIQIDEAALR } \\ \text { TTQIHTHMCY } & \text { SNFNDIIHSI } \\ \text { AGIGPGVYDI } & \text { HSPRIPSTKE } \\ \text { SEVKPALKNM } & \text { VDAAKLLRT }\end{array}$

C.

\begin{tabular}{|l|c|c|c|c|c|}
\hline Protein name & $\begin{array}{c}\text { Accession } \\
\text { number }\end{array}$ & Mass & Score & pI & Matches \\
\hline L-ascorbate oxidase-like protein & XP_010093150.1 & 60499 & 173 & 9.09 & 26 \\
coverage (\%)
\end{tabular}

Protein sequence coverage (Matched peptides shown in bold red):

\begin{abstract}
1 MARAEDPYLF
51 LNVFNNIDEP

101 QIGSYFYYPT

151 TESHSTLRKF

201 RICNVGLKNS

251 TADKAPKDYL

301 WSLNQFRSFR

351 RYAINGVSHV

401 NVVNQTFRNF

451 NLLDAVSRHT

501 VQSPARSLRD
\end{abstract}

SPLGVPQQGI RKNSWQDGVL GGLRVNSRLL DGVLINGKSA KLVEMEGSHT VLTGKGIIRY NPQGSYHYGK YYQVADKVFK SLQTWHLDGY IMLTFDNAGM CGVVKDLPWP
LINGQFPGPN GTNCPILPGT IPVPYADPED KSDGSDEPLF VQNTYESLDV TNAKPAPPSP INITRTIKLV YDIISDEPPA SFFAVAIEPG WNLRSELTER PPYSI

INSTTNNNIV
NFTYRFQVKD
DYTILIGDWY
TMKPGKIYKY
HVGQCFAVLV
DVVEAPVGWA
NSAVRVQGKL
NAGDKITVAT
RWSPDKRSRY
RYLGQQLYIS

D.

\begin{tabular}{|c|c|c|c|c|c|c|}
\hline Protein name & $\begin{array}{c}\text { Accession } \\
\text { number }\end{array}$ & Mass & Score & pI & Matches & $\begin{array}{c}\text { Protein } \\
\text { sequence } \\
\text { coverage (\%) }\end{array}$ \\
\hline L-ascorbate oxidase-like protein & XP_010093149.1 & & 87 & 9.61 & 18 & 21 \\
\hline
\end{tabular}

Protein sequence coverage (Matched peptides shown in bold red):

$\begin{array}{rlllll}\mathbf{1} & \text { MRRVIFVTWL } & \text { VLLSAVVQLR } & \text { AEDPYLFFTW } & \text { NVTYGTISPL } & \text { GVPQQGILIN } \\ \mathbf{5 1} & \text { GQFPGPNINS } & \text { TTNNNIVLNV } & \text { LNNLDEPFLL } & \text { TWTGVQHRKN } & \text { SWQDGVVGTN } \\ \mathbf{1 0 1} & \text { CPIPPGKNFT } & \text { YHFQVKDQIG } & \text { SYIYYPTTAV } & \text { HRAAGAFGGL } & \text { RVNSRLLIPV } \\ \mathbf{1 5 1} & \text { PYADPEDDYT } & \text { VLIGDWYVKS } & \text { HKTLKNFLDS } & \text { GRSLGRPDGV } & \text { LINGKSGNDK } \\ \mathbf{2 0 1} & \text { KPLFTMKPGK } & \text { TYKYRICNVG } & \text { LKDSLNFRIQ } & \text { DHPMKLVEME } & \text { GSHTVQNTYE } \\ \mathbf{2 5 1} & \text { SLDVHVGQCF } & \text { SVLVTADKAP } & \text { KEYYMVASTR } & \text { FTKTVLTGKA } & \text { IIRYTNGRKG } \\ \mathbf{3 0 1} & \text { SASLKNIPEA } & \text { PVGWAWSLNQ } & \text { FRSFRWNLTA } & \text { SAARPNPQGS } & \text { YHYGKIPITR } \\ \mathbf{3 5 1} & \text { TIKIVNSASR } & \text { VKGKLRYGIN } & \text { GVSHVNPVTP } & \text { LKLAEYYGVA } & \text { DKVFKYLIK } \\ \mathbf{4 0 1} & \text { DEPPKKLSGE } & \text { VTLAPNVVNQ } & \text { TFRNFVEIIF } & \text { ENHEKSLQSW } & \text { HLAGYSFFAV } \\ \mathbf{4 5 1} & \text { SIEPGRWRPE } & \text { KRKNYNLLDA } & \text { VSRHTIQVYP } & \text { KSYAAVLLTF } & \text { DNAGMWNLRS } \\ \mathbf{5 0 1} & \text { ELTENRYLGQ } & \text { QLYISVLSPA } & \text { RSLRDEYNMP } & \text { DNALLCGIVK } & \text { DLPKPHPYTI }\end{array}$


Table S2. Protein identification of band $2(79 \mathrm{kDa})$, L-ascorbate oxidase-like protein, protein score 103 (A).

A.

\begin{tabular}{|l|c|c|c|c|c|c|}
\hline Protein name & $\begin{array}{c}\text { Accession } \\
\text { number }\end{array}$ & Mass & Score & pI & Matches & $\begin{array}{c}\text { Protein } \\
\text { sequence } \\
\text { coverage (\%) }\end{array}$ \\
\hline L-ascorbate oxidase-like protein & XP_010093150.1 & 60499 & 103 & 9.09 & 22 & 23 \\
\hline
\end{tabular}

Protein sequence coverage (Matched peptides shown in bold red):

$\begin{array}{rlllll}\mathbf{1} & \text { MARAEDPYLF } & \text { FTWNVTYGTI } & \text { SPLGVPQQGI } & \text { LINGQFPGPN } & \text { INSTTNNNIV } \\ \mathbf{5 1} & \text { LNVFNNIDEP } & \text { ILFTWLGIQQ } & \text { RKNSWQDGVL } & \text { GTNCPILPGT } & \text { NFTYRFQVKD } \\ \mathbf{1 0 1} & \text { QIGSYFYYPT } & \text { TAIHRAAGGF } & \text { GGLRVNSRLL } & \text { IPVPYADPED } & \text { DYTILIGDWY } \\ \mathbf{1 5 1} & \text { TESHSTLRKF } & \text { LDIGRSLGRP } & \text { DGVLINGKSA } & \text { KSDGSDEPLF } & \text { TMKPGKIYKY } \\ \mathbf{2 0 1} & \text { RICNVGLKNS } & \text { LNFRIQGHPL } & \text { KLVEMEGSHT } & \text { VQNTYESLDV } & \text { HVGQCFAVLV } \\ \mathbf{2 5 1} & \text { TADKAPKDYL } & \text { VVASTRFTKN } & \text { VLTGKGIIRY } & \text { TNAKPAPPSP } & \text { DVVEAPVGWA } \\ \mathbf{3 0 1} & \text { WSLNQFRSFR } & \text { WNLTSSAARP } & \text { NPQGSYHYGK } & \text { INITRTIKLV } & \text { NSAVRVQGKL } \\ \mathbf{3 5 1} & \text { RYAINGVSHV } & \text { DPYTPLKLAE } & \text { YYQVADKVFK } & \text { YDIISDEPPA } & \text { NAGDKITVAT } \\ \mathbf{4 0 1} & \text { NVVNQTFRNF } & \text { VEIIFENHEK } & \text { SLQTWHLDGY } & \text { SFFAVAIEPG } & \text { RWSPDKRSRY } \\ \mathbf{4 5 1} & \text { NLLDAVSRHT } & \text { IQVFPKSWAA } & \text { IMLTFDNAGM } & \text { WNLRSELTER } & \text { RYLGQQLYIS } \\ \mathbf{5 0 1} & \text { VQSPARSLRD } & \text { EYNMPDNALL } & \text { CGVVKDLPWP } & \text { PPYSI } & \end{array}$

Table S3. Protein identification of band 3 (68 kDa), Subtilisin-like protease SDD1, protein score 115 (A), Phosphoglucomutase, protein score $107(\mathrm{~B})$.

A.

\begin{tabular}{|c|c|c|c|c|c|c|}
\hline Protein name & $\begin{array}{c}\text { Accession } \\
\text { number }\end{array}$ & Mass & Score & pI & Matches & $\begin{array}{c}\text { Protein } \\
\text { sequence } \\
\text { coverage (\%) }\end{array}$ \\
\hline Subtilisin-like protease SDD1 & XP_010108074.1 & 85546 & 115 & 5.56 & 19 & 20 \\
\hline
\end{tabular}

Protein sequence coverage (Matched peptides shown in bold red):

$\begin{array}{rlllll}\mathbf{1} & \text { MEWKALNLVY } & \text { LFVSLFIILN } & \text { CSDLVGADYQ } & \text { KMKLVFEKSA } & \text { KIEADHDHHD } \\ \mathbf{5 1} & \text { RISSLKTYIV } & \text { HVKKPQISGV } & \text { LSVSDQDLKA } & \text { WYQTFLPSTT } & \text { PTIATTRSSH } \\ \mathbf{1 0 1} & \text { YPRLVHAYKN } & \text { VVSGFAARLT } & \text { ADEVKAMEKK } & \text { DGFVSAREEK } & \text { IYSLHTTHTP } \\ \mathbf{1 5 1} & \text { KFLGLFQGLG } & \text { LWNDSRLGEG } & \text { VIVGLLDTGI } & \text { WPDHPSFSDE } & \text { GLPPPPAKWR } \\ \mathbf{2 0 1} & \text { GKCDFTGTEC } & \text { NNKLIGARDF } & \text { VTSTKSTGTK } & \text { SPSGQPPFDL } & \text { EGHGTHTSST } \\ \mathbf{2 5 1} & \text { AAGNFVSGAN } & \text { AFGMANGTAA } & \text { GIAPRAHLAM } & \text { YRQENEEYLQ } & \text { YLCPVCAEGC } \\ \mathbf{3 0 1} & \text { SEADILAALD } & \text { AAIEDGVDVL } & \text { SLSLGGGSAP } & \text { FYFDSIAIGA } & \text { FAAIQKGIIV } \\ \mathbf{3 5 1} & \text { SCSAGNEGPD } & \text { YFTLSNEAPW } & \text { ILTVGASTVD } & \text { RKIKADAILG } & \text { NGEVLEGESL } \\ \mathbf{4 0 1} & \text { NQLAPFDSSK } & \text { PYPLIYPGAS } & \text { GNESVKYCAP } & \text { GSLQSLDVKG } & \text { KIVACDRGGG } \\ \mathbf{4 5 1} & \text { IARIDKGTEV } & \text { KSAGGIAMIL } & \text { MNEKIDGFST } & \text { LADAHVLPAT } & \text { HVSFAASLKI } \\ \mathbf{5 0 1} & \text { KAYIKSSSSP } & \text { LATILFKGTV } & \text { IGDSHAPVVT } & \text { SFSSRGPSEA } & \text { SIGILKPDII } \\ \mathbf{5 5 1} & \text { GPGVSILAAW } & \text { PVSVDNSTTS } & \text { GKATFNMISG } & \text { TSMSCPHLSG } & \text { VAALLKSSHP } \\ \mathbf{6 0 1} & \text { EWSPATIKSA } & \text { ILTTADVSNL } & \text { GGGAILDEKA } & \text { SPADVFATGA } & \text { GHVNPSKANN } \\ \mathbf{6 5 1} & \text { PGLIYDIEPE } & \text { DYIPYLCGLN } & \text { YTDDQVSTIT } & \text { QTTVKCSEVQ } & \text { SIPESQLNYP } \\ \mathbf{7 0 1} & \text { TFTVLLGNER } & \text { LSYTRTVTNV } & \text { GEANSEYTLD } & \text { VYPPVGTGIN } & \text { VTPNKLTFTE } \\ \mathbf{7 5 1} & \text { VNQKAEYKIE } & \text { IIQVSGPGRS } & \text { TNPFEQGYLV } & \text { WKSDKYSVRS } & \text { QITAIFAV }\end{array}$

B.

\begin{tabular}{|c|c|c|c|c|c|c|}
\hline Protein name & $\begin{array}{l}\text { Accession } \\
\text { number }\end{array}$ & Mass & Score & pI & Matches & $\begin{array}{c}\text { Protein } \\
\text { sequence } \\
\text { coverage }(\%)\end{array}$ \\
\hline Phosphoglucomutase & XP_010101975.1 & 63757 & 107 & 5.65 & 22 & 27 \\
\hline
\end{tabular}


Protein sequence coverage (Matched peptides shown in bold red):

$\begin{array}{rlllll}\mathbf{1} & \text { MVVFNVSKVE } & \text { TTPFDGQKPG } & \text { TSGLRKKVKV } & \text { FVQPHYLQNF } & \text { VQSTFNALSG } \\ \mathbf{5 1} & \text { EKVRGATLVV } & \text { SGDGRYYSKD } & \text { AIQIIIMMAA } & \text { ANGVRRIWVG } & \text { QNGLLSTPAV } \\ \mathbf{1 0 1} & \text { SAVIRERTGV } & \text { DGSRASGAFI } & \text { LTASHNPGGP } & \text { HEDFGIKYNM } & \text { ENGGPAPEAI } \\ \mathbf{1 5 1} & \text { TDKIYENTKT } & \text { IKEYLIADLP } & \text { DVDISTIGLT } & \text { SFNGPEGQFD } & \text { VEVFDSASDY } \\ \mathbf{2 0 1} & \text { IKLMKSIFDF } & \text { ESIRKLLTSP } & \text { KFTFCFDALH } & \text { GVAGAYAKRI } & \text { FVEELGAQES } \\ \mathbf{2 5 1} & \text { SLLNCTPKED } & \text { FGGGHPDPNL } & \text { TYAKELVARM } & \text { GLGKSDTQEE } & \text { PPEFGAAADG } \\ \mathbf{3 0 1} & \text { DADRNMILGK } & \text { RFFVTPSDSV } & \text { AIIAANAVDA } & \text { IPYFSAGLKG } & \text { VARSMPTSAA } \\ \mathbf{3 5 1} & \text { LDVVAKHLNL } & \text { KFFEVPTGWK } & \text { FFGNLMDAGL } & \text { CSICGEESFG } & \text { TGSDHIREKD } \\ \mathbf{4 0 1} & \text { GIWAVLAWLS } & \text { ILAHKNKENL } & \text { GGEKLVTVEK } & \text { IVRQHWATYG } & \text { RHYYIRYDYE } \\ \mathbf{4 5 1} & \text { NVDAGAAKEL } & \text { MAYLVKLQSS } & \text { LPEVNEIVHG } & \text { ACPDVSKVVH } & \text { GDEFEYKDSV } \\ \mathbf{5 0 1} & \text { DGSISKHQGI } & \text { RYLFEDGSRL } & \text { VFRLSGTGSE } & \text { GATIRLYIEQ } & \text { YEKDPSKTGR } \\ \mathbf{5 5 1} & \text { DSQEALAPLV } & \text { EVAIKLSKMQ } & \text { EFTGRSAPTV } & \text { IT } & \end{array}$

Table S4. Protein identification of band $4(56 \mathrm{kDa})$, hypothetical protein L484_006703, protein score 71 (A).

A.

\begin{tabular}{|c|c|c|c|c|c|c|}
\hline Protein name & $\begin{array}{l}\text { Accession } \\
\text { number }\end{array}$ & Mass & Score & pI & Matches & $\begin{array}{c}\text { Protein } \\
\text { sequence } \\
\text { coverage (\%) }\end{array}$ \\
\hline hypothetical protein L484_006703 & XP_010112623.1 & 53747 & 71 & 6.01 & 6 & 9 \\
\hline
\end{tabular}

Protein sequence coverage (Matched peptides shown in bold red):

$\begin{array}{rlllll}\mathbf{1} & \text { MGHCGGVVLV } & \text { TLALFCFFVS } & \text { VKGEANFEDD } & \text { FLFSLAANHD } & \text { YKDALGKGIL } \\ \mathbf{5 1} & \text { FFEGQRSGKL } & \text { PSSQRVTWRG } & \text { DSALSDGKPE } & \text { GANLVGGYYD } & \text { AGDNVKFVWP } \\ \mathbf{1 0 1} & \text { MAFSVCLLSW } & \text { AAVEYQQEIS } & \text { SANQLKHLRD } & \text { AIRWGADFIL } & \text { EAHTSPTTLY } \\ \mathbf{1 5 1} & \text { TQVGDGNSDH } & \text { QCWERPEDMD } & \text { TSRALFKITS } & \text { NSPGSEAAAE } & \text { AAAALAAASI } \\ \mathbf{2 0 1} & \text { VFKGVDSNYS } & \text { SRLLRNSEST } & \text { NIEDLTKVLV } & \text { HSTAHTLAIS } & \text { CLILQTNIED } \\ \mathbf{2 5 1} & \text { LTKVLVHSIA } & \text { HTLAISETPS } & \text { QEFYGGKKDL } & \text { EKYKNDIESF } & \text { ICAVMPGSSS } \\ \mathbf{3 0 1} & \text { VQIRTTPGGL } & \text { LYTRDSSNLQ } & \text { YVTTVTMALL } & \text { IHSKTISAAQ } & \text { SGGVQCGSAK } \\ \mathbf{3 5 1} & \text { FSASQIRAFA } & \text { KSQVDYILGN } & \text { NPMKTSYMVG } & \text { FGSKYPTQLH } & \text { HRGASIPSIR } \\ \mathbf{4 0 1} & \text { VHPTKVGCNE } & \text { GQNLYFSTK } & \text { PNPNIHVGAL } & \text { VGGPNSNDQF } & \text { NDVRSDYSHL } \\ \mathbf{4 5 1} & \text { EPTSYINAAF } & \text { VGSVAAFLAE } & \text { NNENYLQLSR } & \text { VKTTAELYTA } & \text { NI }\end{array}$

Table S5. Protein identification of band 5 (15 kDa), hypothetical protein L484_025194, protein score 73 (A).

A.

\begin{tabular}{|c|c|c|c|c|c|c|}
\hline Protein name & $\begin{array}{c}\text { Accession } \\
\text { number }\end{array}$ & Mass & Score & pI & Matches & $\begin{array}{c}\text { Protein } \\
\text { sequence } \\
\text { coverage (\%) }\end{array}$ \\
\hline hypothetical protein L484_025194 & XP_010106438.1 & 16003 & 73 & 5.66 & 9 & 48 \\
\hline
\end{tabular}

Protein sequence coverage (Matched peptides shown in bold red):

$\begin{array}{rlllll}\mathbf{1} & \text { MASKLSPEFA } & \text { YTVVYVKDVA } & \text { RCVEFYKNAF } & \text { GFSVRRLDES } & \text { HRWGELESGQ } \\ \mathbf{5 1} & \text { TTIAFTPLHQ } & \text { HETDDLTGSV } & \text { QTPEYARDRA } & \text { PVEVCFVYSD } & \text { VDAAYKKAVE } \\ \mathbf{1 0 1} & \text { NGAVPVSEPE } & \text { QKEWGQKVGY } & \text { LRDLNGIVVR } & \text { IGSHVHPPKH } & \text { D }\end{array}$

\section{ELISA results}

Specific IgE antibodies were only detected in two sera samples (patients E and K) with standardized commercial M. alba pollen extract possibly due to absence or inadequate concentration of allergenic protein(s) in this extract.

\section{Discussion}

In this study, a 1D-immunoproteomics approach provided the first study of the allergenic protein profile of the $M$. alba (white mulberry) pollen extract, which was confirmed as an allergen for 11 patients living in Istanbul, Turkey. It was found that $M$. alba pollen contains many allergenic proteins between $15-100 \mathrm{kDa}$. The most prominent bands are proteins of approximately $55-100 \mathrm{kDa}$ in the majority of patients.

Until now, only two distinct Ig-E binding proteins around 10 - and $18 \mathrm{kDa}$ have been reported for M. alba in a case report. ${ }^{13}$ The $18 \mathrm{kDa}$ protein was proposed to be in accordance with the Bet v1 allergen and its homologs, however, identification of 
this protein has not been achieved. Our study revealed that the allergenic proteins of $M$. alba pollen have a molecular weight of $82,79,68,56$ and $15 \mathrm{kDa}$. Thus it can be suggested that $M$. alba pollen contains allergenic proteins with higher molecular weight than known allergenic proteins with low molecular weight as in the other Morus species and common tree pollens. ${ }^{13}$ In fact, some IgE reactive proteins between $36-98 \mathrm{kDa}$ have also been detected in paper mulberry (M. papyrifera) grown in Pakistan, however in this study, the authors focused only on a $10 \mathrm{kDa}$ protein. ${ }^{10}$

After MS/MS analyses of the major protein bands in 1D-gel, methionine synthase (MetE) (Band 1) showed the highest protein score (353) among all identified IgE-binding proteins. This protein with a MW of $85 \mathrm{kDa}$ belongs to the vitamin-B12 independent methionine synthase (MetE) family and catalyzes the transfer of a methyl group from 5-methyltetrahydrofolate $\left(\mathrm{N}^{5}-\mathrm{MeTHF}\right)$ to homocysteine resulting in methionine formation. ${ }^{22}$ Two reports were published on allergenic MetEs among plants, but never in M. alba. In the first study Chardin et al. showed that the amino acid sequence of a high molecular weight allergenic protein (approximately $80 \mathrm{kDa}$ ) from the oilseed rape (Brassica napus) pollen was very similar to that of the cobalamin-independent MetE of Arabidopsis thaliana (AtMetE). ${ }^{23}$ The authors demonstrated that this $80 \mathrm{kDa}$ protein represented an allergen from the oilseed rape pollen. In 2011, a study from Iran identified the cobalamin-independent MetE as a new allergen of Salsola kali pollen. ${ }^{22}$ This study showed that $S$. kali MetE shares a high degree of amino acid sequence homology with the MetE from other plants including Beta vulgaris (Amaranthaceae) (91\%), Solanum tuberosum (89\%), and Arabidopsis thaliana (88\%). The new allergen was designated Sal k 3 by the WHO/IUIS Allergen Nomenclature Subcommittee. Our study is the first report on allergenic MetE in $M$. alba. Although we propose MetE as the major allergen of $M$. alba we have no data regarding the cross-reactivity to Amaranthaceae pollens in our patients.

Our results are also partly correlated with the findings of Erler et al. for birch pollen. ${ }^{24}$ These researchers evaluated the profile of allergenic and non-allergenic proteins in extracts of birch pollen from different origins by MS-based proteomics, and they detected MetEs with high scores. Thus, M. alba pollen might be expected to display cross-reactivity with birch pollen through these proteins. However, we detected skin test positivity for birch pollen in only 4 patients (Table 1 ).

Six other proteins were also detected in MS analyses with lower protein scores. The allergenicity of L-ascorbate oxidase -like protein (Band 1,2) could be explained by the carbohydrate epitope in the glycan moiety of this protein as in the previous studies with Cupressaceae pollens ${ }^{21}$ and olive pollens. ${ }^{25}$ Subtilisine-like protease and phosphoglucomutase (Band 3) were already described in other species as potential allergenic proteins. ${ }^{24,26-29}$

Band 4 and band 5 also allowed the identification of potential allergenic proteins: hypothetical protein L484_006703, a protein from the glycosyl hydrolase family 9, and hypothetical protein L484_025194 with a conserved domain found in a variety of structurally related metalloproteins like glyoxalase I or dioxygenases. There are 10 records related to glycosyl hydrolases in the allergome database (http://www.allergome. org/script/search_step2.php). Two belong to olive tree-derived allergens, Ole e 10 and Ole e 10.0101. A novel allergenic glyoxalase has been demonstrated with rice, and the role of indoleamine 2,3-dioxygenase (IDO), an initiator of tryptophan catabolism, on allergic inflammation has been explored. ${ }^{30-31}$

Although this study provides new data regarding the allergenic proteins in $M$. alba pollen, it contains some limitations because ELISA results did not concur with the immunoproteomic results. The discrepancy might be explained by the failure to detect low antibody levels. Further studies on sIgE detection in patients' sera are needed. In addition, the results should be supported by other diagnostic tests such as a basophil activation test.

In conclusion, IgE-binding proteins detected in our study are relatively different than those reported earlier, probably as a result of the region where the pollen samples were collected as it is well known that the pollen content and the allergenicity are affected by the climate and other environmental conditions. ${ }^{32}$ Methionine synthase is a potential allergenic protein in Morus alba pollen. Further studies such as 2D-gel electrophoresis and other MS techniques, ELISA testing and extending the clinical data are in progress for a better understanding of the allergy mechanism of mulberries.

\section{Acknowledgements}

This study was supported by the Research Fund of Istanbul University (Project no. 3063 and Project no. 30217) and the BioHealth Computing Erasmus Mundus program (512383-1-2010$1-\mathrm{FR})$.

\section{Conflict of interest}

The authors declare no conflict of interest.

\section{References}

1. Traidl-Hoffmann C, Kasche A, Menzel A, Jakob T, Thiel M, Ring J, et al. Impact of pollen on human health: More than allergen carriers? Int Arch Allergy Immunol. 2003;131:1-13.

2. D’Amato G, Cecchi L, Bonini S, Nunes C, Annesi-Maesano I, Behrendt H, et al. Allergenic pollen and pollen allergy in Europe. Allergy. 2007;62:976-90.

3. Alessandri C, Zennaro D, Zaffiro A, Mari A. Molecular allergology approach to allergic diseases in the paediatric age. Ital J Pediatr. 2009;35: 29-40.

4. Nakamura R, Teshima R. Proteomics-based allergen analysis in plants. J Proteomics. 2013;93: 40-9.

5. Rodriguez R, Villalba M, Batanero E, Palomares O, Salamanca G. Emerging pollen allergens. Biomed Pharmacother. 2007;61:1-7.

6. Radauer C, Breiteneder H. Pollen allergens are restricted to few protein families and show distinct patterns of species distribution. J Allergy Clin Immunol. 2006;117:141-7.

7. Ferreira F, Hawranek T, Gruber P, Wopfner N, Mari A. Allergic cross -reactivity: from gene to the clinic. Allergy. 2004;59:243-67.

8. Miljkovic VM, Nikolic GS, Nikolic LB, Arsic BB. Morus species through centuries in pharmacy and as food. Advanced Technologies. 2014;3:111-5.

9. Ciardiello MA, Palazzo P, Bernardi ML, Carratore V, Giangrieco I, Longo $\mathrm{V}$, et al. Biochemical, immunological and clinical characterization of a cross-reactive nonspecific lipid transfer protein 1 from mulberry. Allergy. 2010;65:597-605.

10. Micheal S, Wangorsch A, Wolfheimer S, Foetisch K, Minhas K, Scheurer $\mathrm{S}$, et al. Immunoglobulin E reactivity and allergenic potency of Morus papyrifera (paper mulberry) pollen. J Investig Allergol Clin Immunol. 2013;23:168-75.

11. Targow AM. The mulberry tree: a neglected factor in respiratory allergy in SouthernCalifornia. Ann Allergy. 1971;29:318-22. 
12. Munoz FJ, Delgado J, Palma JL, Gimenez MJ, Monteseirin FJ, Conde J. Airborne contact urticaria due to mulberry (Morus alba) pollen. Contact Dermatitis. 1995;32:61.

13. Navarro AM, Orta JC, Sánchez MC, Delgado J, Barber D, Lombardero M. Primary sensitization to Morus alba. Allergy. 1997;52:1144-52.

14. Iacovacci P, Afferni C, Barletta B, Tinghino R, Felice GD, Pini C, et al. Juniperus oxycedrus: A new allergenic pollen from the Cupressaceae family. J Allergy Clin Immunol. 1998;101(6):755-61.

15. Lebel B, Bousquet J, Morel A, Chanal I, Godard P, Michel FB. Correlation between symptoms and the threshold for release of mediators in nasal secretions during nasal challenge with grass-pollen grains. J Allergy Clin Immunol. 1988;82:869-77.

16. Terrien MH, Rahm F, Fellrath JM, Spertini F. Comparison of the effects of terfenadine with fexofenadine on nasal provocation tests with allergen. J Allergy Clin Immunol. 1999;103:1025-30.

17. Cimarra M, Robledo T. Aplicación en provocación nasal específi ca. In: Valero A, Fabra JM, Márquez F, Orus C, Picado C, Sastre J, Sierra JI, editors. Manual de Rinomanometría Acústica. Barcelona: MRA Médica, 2001.p. 55-63. Spanish.

18. Walker JM. SDS polyacrylamide gel electrophoresis of proteins. In: Walker JM, editor. The Protein Protocols Handbook, Second edition. Totowa, New Jersey: Humana Press, 2002. p. 61-7.

19. He N, Zhang C, Qi X, Zhao S, Tao Y, Yang G, et al. Draft genome sequence of the mulberry tree Morus notabilis. Nat Commun. 2013;4:1-9.

20. Li T, Qi X, Zeng Q, Xiang Z, He N. MorusDB: a resource for mulberry genomics and genome biology. Database (Oxford). 2014; 2014:bau054.

21. Iacovacci $\mathrm{P}$, Pini $\mathrm{C}$, Afferni $\mathrm{C}$, Barletta $\mathrm{B}$, Tinghino $\mathrm{R}$, Schininà $\mathrm{E}$, et al. A monoclonal antibody specific for a carbohydrate epitope recognizes an IgE-binding determinant shared by taxonomically unrelated allergenic pollens. Clin Exp Allergy. 2001;31:458-65.

22. Assarehzadegan MA, Sankian M, Jabbari F, Tehrani M, Falak R, Varasteh A-R. Identification of methionine synthase (Sal k 3), as a novel allergen of Salsola kali pollen. Mol Biol Rep. 2011;38:65-73.
23. Chardin H, Mayer C, Senechal H, Tepfer M, Desvaux FX, Peltre G. Characterization of high-molecular-mass allergens in oilseed rape pollen. Int Arch Allergy Immunol. 2001;125:128-34.

24. Erler A, Hawranek T, Krückemeier L, Asam C, Egger M, Ferreira F, et al. Proteomic profiling of birch (Betula verrucosa) pollen extracts from different origins. Proteomics. 2011;11:1486-98.

25. Batanero E, Villalba M, Monsalve RI, Rodríguez R. Cross-reactivity between the major allergen from olive pollen and unrelated glycoproteins: evidence of an epitope in the glycan moiety of the allergen. J Allergy Clin Immunol. 1996;97:1264-71.

26. Cuesta-Herranz J, Pastor C, Figueredo E, Vidarte L, de las Heras M, Durán C, et al. Identification of cucumisin (Cuc m 1), a subtilisin-like endopeptidase, as the major allergen of melon fruit. Clin Exp Allergy. 2003; 33:827-33.

27. Ibrahim AR, Kawamoto S, Mizuno K, Shimada Y, Rikimaru S, Onishi N, et al. Molecular cloning and immunochemical characterization of a new Japanese cedar pollen allergen homologous to plant subtilisin-like serine protease. World Allergy Organ J. 2010;3:262-5.

28. Sankian M, Talebi F, Moghadam M, Vahedi F, Azad FJ, Varasteh AR. Molecular cloning and expression of Cucumisin (Cuc m 1), a subtilisin-like protease of Cucumis melo in Escherichia coli. Allergol Int. 2011;60:61-7.

29. Tripathi P, Nair S, Singh BP, Arora N. Molecular and immunological characterization of subtilisin like serine protease, a major allergen of Curvularia lunata. Immunobiology. 2011;216:402-8.

30. Usui Y, Nakase M, Hotta H, Urisu A, Aoki N, Kitajima K, et al. A 33-kDa allergen from rice (Oryza sativa L. Japonica). J Biol Chem. 2001;276: 11376-81.

31. von Bubnoff D, Bieber T. The indoleamine 2,3-dioxygenase (IDO) pathway controls allergy. Allergy. 2012;67:718-25.

32. D'Amato G. Effects of climatic changes and urban air pollution on the rising trends of respiratory allergy and asthma. Multidiscip Respir M. 2011;6: 28-37. 